CARA BELAJAR, KREATIVITAS BELAJAR DAN PRESTASI BELAJAR

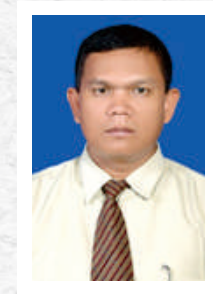

Osco Parmonangan Sijabat lahir di

Pematangsiantar, 01 Oktober 1978. Menyelesaikan studi di jenjang sekolah dasar (SD) tahun 1991, jenjang sekolah menengah pertama (SMP) tahun 1994 dan jenjang sekolah menengah atas (SMA) tahun 1997. Melanjutkan perkuliahan di perguruan tinggi untuk tingkat Strata Satu (S-1) di Universitas HKBP Nommensen lulus tahun 2005, kemudian untuk tingkat Strata Dua (S-2) di Universitas Negeri Medan (UNIMED) lulus tahun 2011 , dan sekarang sedang dalam proses Penyelesaian Disertasi untuk program Doktor (S-3) di Universitas Negeri Medan (UNIMED). Penulis merupakan Dosen tetap universitas HKBP Nommensen sejak tahun 2006. Beberapa karya ilmiah baik berupa buku, jurnal dan artikel yang sudah dihasilkan diantaranya: Perencanaan dan Pengawasan Biaya Produksi Pada Pabrik Tenun CV. Parna Raya Pematangsiantar (Skripsi, 2005), Analisis pengembangan silabus Kurikulum Tingkat Satuan Pendidikan (KTSP) oleh guru-guru di SMP Swasta Nusantara Tanah Jawa Kabupaten Simalungun (Tesis, 2011), Pengaruh Kualitas Pelayanan Terhadap Prestasi Akademik Mahasiswa Program Studi Pendidikan Ekonomi Universitas HKBP Nommensen Pematangsiantar (Prosiding, 2015), Pengembangan Perangkat Pembelajaran dan Penilaian Otentik Berbasis Penerapan Model Pembelajaran Kooperatif Tipe Jigsaw Untuk Meningkatkan Kemampuan Pemecahan Masalah Siswa, (Jurnal, 2017), Thematic Character Based Learning In Primary School (Jurnal, 2019), Konsep Dasar Perencanaan Pembelajaran (Buku, 2013), Konsep Dasar Pembelajaran Microteaching (Buku, 2014), Konsep Dasar Belajar dan Pembelajaran (Buku, 2016), Konsep Dasar Pendidikan IPS di Sekolah Dasar (Buku, 2019), Terakhir penulis menyelesaikan buku yang berjudul Perkembangan Peserta Didik Tingkat Dasar dan Menengah (2021). Penulis juga aktif dalam pertemuan ilmiah atau seminar-seminar baik nasional maupun internasional sebagai narasumber/pemakalah dan juga aktif sebagai instruktur PLPG bagi guru-guru yang sertifikasi.

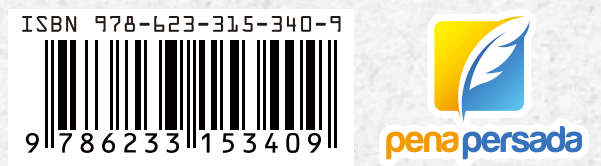

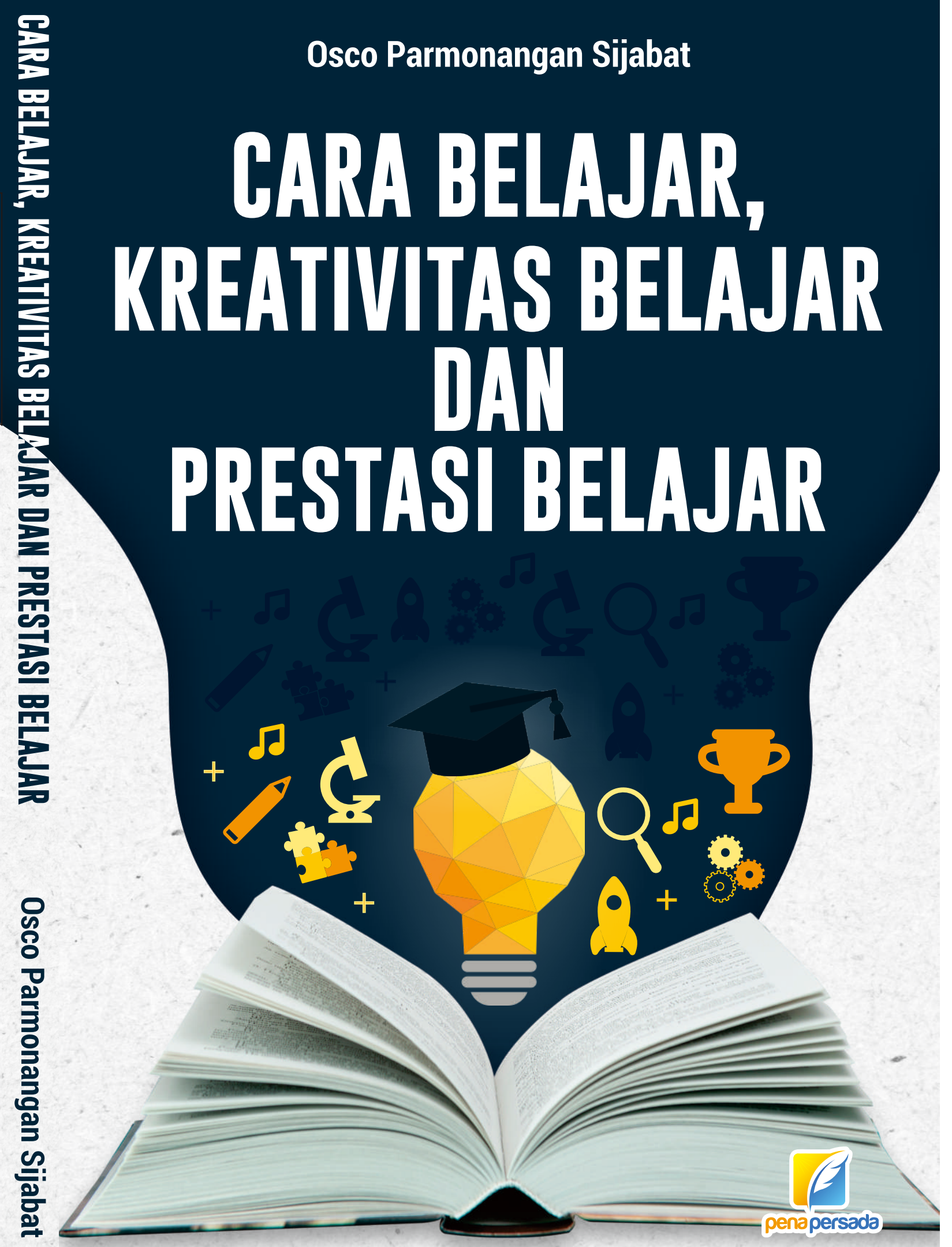


CARA BELAJAR, KREATIVITAS BELAJAR DAN PRESTASI BELAJAR

OSCO PARMONANGAN SIJABAT

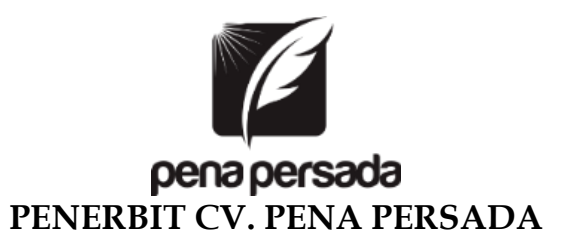




\title{
CARA BELAJAR, KREATIVITAS BELAJAR DAN PRESTASI BELAJAR
}

\author{
Penulis: \\ Osco Parmonangan Sijabat \\ ISBN : 978-623-315-340-9
}

Editor:

Tri Hidayati

Design Cover :

Retnani Nur Briliant

Layout :

Hasnah Aulia

\section{Penerbit CV. Pena Persada \\ Redaksi :}

Jl. Gerilya No. 292 Purwokerto Selatan, Kab. Banyumas

Jawa Tengah

Email : penerbit.penapersada@gmail.com

Website : penapersada.com Phone : (0281) 7771388

\section{Anggota IKAPI}

All right reserved

Cetakan pertama : 2021

Hak Cipta dilindungi oleh undang-undang. Dilarang memperbanyak karya tulis ini dalam bentuk apapun tanpa izin penerbit 


\section{KATA PENGANTAR}

Puji syukur saya panjatkan kepada Tuhan Yang Maha Esa, karena atas berkat dan rahmat-Nya, saya dapat menyelesaikan buku monograf ini. Penulisan monograf merupakan buah karya dari pemikiran penulis yang diberi judul " CARA BELAJAR, KREATIFITAS BELAJAR DAN PRESTASI BELAJAR". Saya menyadari bahwa tanpa bantuan dan bimbingan dari berbagai pihak sangatlah sulit bagi saya untuk menyelesaikan karya ini. Oleh karena itu, saya mengucapkan banyak terima kasih pada semua pihak yang telah membantu penyusunan buku ini. Sehingga buku ini bisa hadir di hadapan pembaca.

Kajian dalam buku ini bertujuan untuk mengetahui ada tidaknya pengaruh cara belajar yang efisien dan kreativitas belajar terhadap prestasi belajar Akuntansi Keuangan siswa kelas XI SMK Swasta Teladan Tanah Jawa. Yang menjadi permasalahan dalam kajian ini adalah apakah pengaruh cara belajar yang efisien dan kreativitas belajar siswa pada pelajaran Akuntansi Keuangan di kelas XI SMK Swasta Teladan Tanah Jawa T.A. 2019/2020. Adapun Sampel dalam kajian ini adalah seluruh kelas XI sejumlah 60 orang. Instrument yang digunakan untuk mengumpulkan data pengaruh cara belajar yang efisien dan kreativitas belajar adalah dengan menggunakan angket langsung. Sedangkan data tentang prestasi belajar Akuntansi Keuangan diperoleh melalui tes kemampuan pelajaran Akuntansi Keuangan.

Pengaruh cara belajar yang efisien dengan kreativitas belajar siswa adalah 0,46 (cukup) yang berarti ada pengaruh cara belajar yangh efisien dengan kreativitas belajar. Interaksi gabungan antara cara belajar yang efisien dan kreativitas belajar terhadap prestasi belajar siswa pada pelajaran Akuntansi Keuangan di kelas XI SMK Swasta Teladan Tanah Jawa T.A. 2019/2020 adalah 0,61 (tinggi) yang berarti ada pengaruh cara belajar yang efisien dan kreativitas belajar terhadap prestasi belajar siswa. 
Penulis menyadari bahwa buku ini masih jauh dari kesempurnaan. Oleh karena itu kritik dan saran yang membangun sangat dibutuhkan guna penyempurnaan buku ini. Akhir kata saya berharap Tuhan Yang Maha Esa berkenan membalas segala kebaikan semua pihak yang telah membantu. Semoga buku ini akan membawa manfaat bagi pengembangan ilmu pendidikan. 


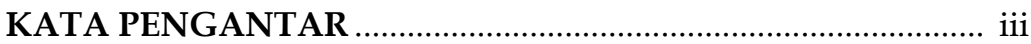

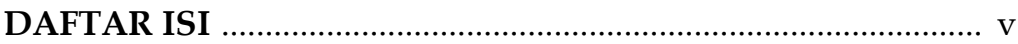

BAB I UPAYA PERBAIKAN PENDIDIKAN ……....................... 1

BAB II CARA BELAJAR YANG EFISIEN

A. Arti penting cara belajar yang efisien ...................................... 4

B. Petunjuk cara belajar yang efisien. ........................................ 5

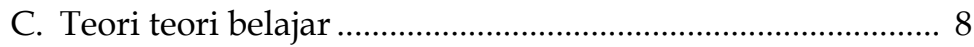

D. Prinsip-prinsip belajar ..................................................... 10

BAB III KREATIVITAS BELAJAR

A. Arti pentingnya kreativitas................................................. 14

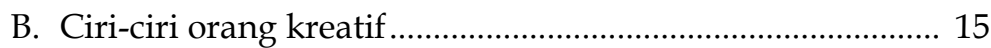

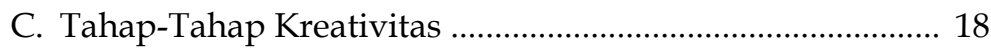

D. Hambatan untuk menjadi lebih kreatif................................ 21

BAB IV PRESTASI BELAJAR

A. Arti pentingnya prestasi belajar........................................... 23

B. Faktor yang mempengaruhi prestasi belajar......................... 24

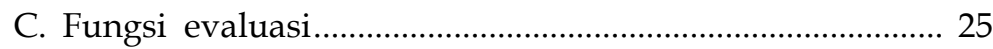

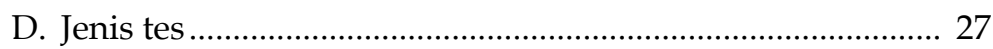

E. Langkah-langkah penyusunan Tes ....................................... 31

\section{BAB V METODOLOGI}

A. Jenis dan Rancangan Penelitian ............................................. 33

B. Lokasi Penelitian ................................................................... 35

C. Populasi dan Sampel penelitian............................................ 36

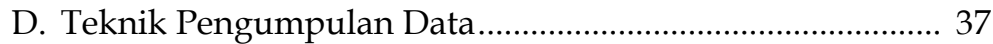

E. Menilai Kualitas Instrument Penelitian ................................. 39

F. Teknik Pengolahan Data dan Analisa Data .......................... 44

G. Pengujian hipotesis................................................................. 46

BAB VI PENGARUH CARA BELAJAR EFISIEN DAN KREATIVITAS BELAJAR PADA PRESTASI ............................ 53

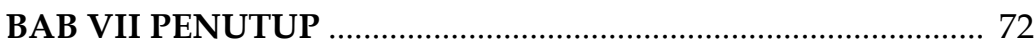

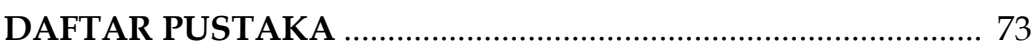


CARA BELAJAR, KREATIVITAS BELAJAR DAN PRESTASI BELAJAR 


\section{BAB I \\ UPAYA PERBAIKAN PENDIDIKAN}

Perkembangan ilmu pengetahuan dan teknologi yang relatif cepat mengakibatkan terjadinya perubahan dalam diri manusia dan hal tersebut mau tidak mau mempengaruhi perkembangan nilai pendidikan. Pendidikan mempunyai peran yang sangat strategis dalam meningkatkan kualitas sumber daya manusia dan upaya mewujudkan cita-cita bangsa Indonesia dalam mewujudkan kesejahteraan umum dan mencerdaskan kehidupan bangsa seperti yang ditegaskan dalam UU No.20 Tahun 2003 tentang Sistem Pendidikan Nasional Bab II pasal 3 menyatakan:

"Pendidikan nasional berfungsi mengembangkan kemampuan dan membentuk watak serta peradaban bangsa yang bermanfaat dalam rangka mencerdaskan kehidupan bangsa, bertujuan untuk berkembangnya potensi peserta didik agar menjadi manusia yang beriman dan bertakwa kepada Tuhan Yang Maha Esa, berakhlak mulia ,sehat, berilmu, cakap ,kreatif, mandiri dan menjadi warga yang demokratis serta bertanggung jawab".

Berbagai upaya telah dilakukan pemerintah dalam meningkatkan kualitas pendidikan di Indonesia seperti:

1. Memberikan bantuan berupa buku paket

2. Pengadaan kelengkapan fasilitas sekolah dalam proses belajar mengajar misalnya: perpustakaan, komputer, laboratorium dan alat praktik lainnya.

3. Penambahan gedung

4. Penambahan guru sebagai staf pengajar

5. Meningkatkan kualitas guru melalui penataran-penataran dan pendidikan lanjutan.

6. Mengadakan seminar-seminar untuk penyempurnaan kurikulum sekolah agar sesuai dengan tuntutan zaman .

7. Meningkatkan kesejahteraan guru yang meliputi pengadaan perumahan guru, penghargaan bagi guru yang berprestasi. 
Akan tetapi kenyataan yang terjadi sekarang tidak sesuai dengan yang dilakukan oleh pemerintah yaitu berbagai upaya demi perbaikan pendidikan. Hal ini dapat dibuktikan dengan hasil ujian yang kurang memuaskan, pekerjaan rumah, nilai Ujian Tengah Semester (UTS), nilai Ujian Akhir Semester (UAS) bahkan nilai Ujian Nasional (UN) yang masih sangat jauh dari yang diharapkan. Ketidakberhasilan siswa tidak semuanya disebabkan oleh kebodohan dan kelemahan intelektualnya, tetapi banyak faktor yang mempengaruhinya serta mempunyai hubungan antara yang satu dengan yang lainnya seperti:

\section{Siswa/Peserta didik itu sendiri}

Hal ini menyangkut cara belajar ,intelegensi (kecerdasan), kesungguhan, kreativitas, keuletan, ketekunan, dan tanggungjawab.

\section{Guru/Tenaga pengajar}

Hal ini menyangkut tentang pengalaman, tingkat pendidikan, kemampuan profesional keguruan, metode mengajar, adanya fasilitas belajar, ketekunan, motivasi belajar serta kreativitas.

\section{Orang tua}

Hal ini menyangkut social Akuntansi Keuangan, tingkat pendidikan orang tua, perhatian ,dukungan, arahan, bimbingan, komunikasi, kepemimpinan, disiplin dan tanggungjawab.

\section{Masyarakat}

Hal ini menyangkut keadaan dan cara hidup, lingkungan tempat tinggal, teman bergaul dan sebagainya.

Dalam proses belajar mengajar sangat diperlukan adanya hubungan yang sangat erat di antara kedua belah pihak yaitu pihak yang mengajar dan pihak yang belajar. Sering ditemukan bahwa dalam proses belajar siswa hanya menerima apa yang diberikan oleh guru dan tidak berusaha untuk mencari sebuah topik yang memerlukan suatu pemecahan.

Kajian dalam buku ini bertujuan untuk mengetahui ada tidaknya pengaruh cara belajar yang efisien dan kreativitas belajar terhadap prestasi belajar Akuntansi Keuangan siswa kelas XI SMK 
Swasta Teladan Tanah Jawa. Yang menjadi permasalahan dalam kajian ini adalah apakah pengaruh cara belajar yang efisien dan kreativitas belajar siswa pada pelajaran Akuntansi Keuangan di kelas XI SMK Swasta Teladan Tanah Jawa T.A. 2019/2020. 


\section{BAB II \\ CARA BELAJAR YANG EFISIEN}

\section{A. Arti penting cara belajar yang efisien}

Cara belajar yang efisien merupakan kegiatan belajar yang dilakukan dalam mempelajari sesuatu. Artinya kegiatan yang seharusnya dilakukan dalam situasi belajar tertentu. Umumnya dalam situasi belajar tertentu diperlukan cara belajar tertentu pula. Walaupun banyak yang mempengaruhi proses dan hasil belajar, namun pada akhirnya yang menentukan adalah pelakunya yaitu individu yang sedang belajar. Siswa di tuntut untuk aktif dalam belajar di sekolah maupun di rumah. Ia juga harus aktif dan kreatif berfikir dalam pemecahan masalah, menggunakan waktunya dengan baik, terarah dan memiliki disiplin yang baik. Belajar dengan teratur sudah merupakan bagian dari cara belajar yang efisien, dimana belajar itu merupakan pedoman mutlak yang tidak bisa diabaikan oleh seseorang dalam hal menuntut ilmu.

Muhibbin Syah (2009:59) mengemukakan bahwa "Perubahan dan kemampuan untuk berubah merupakan batasan dan makna yang terkandung dalam belajar. Disebabkan oleh kemampuan berubah karena belajarlah, maka manusia dapat berkembang lebih jauh dari pada makhlukmakhluk lainnya sehingga ia terbebas dari kemandekan fungsinya sebagai khalifah Tuhan di muka bumi ini".

Banyak siswa yang gagal atau tidak memberi hasil yang baik dalam pelajarannya karena mereka tidak mengetahui cara belajar yang efisien. Penggunaan cara belajar yang efisien dengan tepat akan memperoleh hasil yang baik, sedangkan penggunaan cara belajar yang tidak efisien akan memperoleh hasil yang buruk. Itulah sebabnya mengapa cara belajar tersebut harus dimiliki oleh setiap pelajar dalam diri masing. 
Slameto (2010:76) mengemukakan bahwa "Belajar yang efisien dapat tercapai apabila dapat menggunakan strategi belajar yang tepat. Strategi belajar diperlukan untuk dapat mencapai hasil yang semaksimal mungkin."

Semua manusia yang hidup di muka bumi ini pernah melakukan perbuatan belajar dalam kehidupan sehari hari untuk mencapai berbagai kebutuhannya. Sejak dari bayi sampai dengan dewasa bahkan sampai tua manusia tak henti hentinya belajar untuk menambah ilmu. Tentunya untuk mencapai tujuan tersebut harus didukung dengan cara-cara belajar yang baik dan strategi yang tepat pula.

The Liang Gie (1982:5) mengemukakan bahwa "Suatu kegiatan dapat dikatakan efisien kalau dengan usaha tertentu memberikan hasil yang terbesar. Terbesar mengenai kuantitas atau kualitas hasil itu".

Perlu untuk diperhatikan bahwa hasil belajar tidak datang dengan sendirinya tetapi diperoleh dari usaha belajar yang keras. Suatu kegiatan belajar dapat dikatakan efisien jika prestasi belajar yang diinginkan dapat dicapai dengan usaha yang minimal. Usaha ini meliputi tenaga dan pikiran, waktu, peralatan belajar, dan lain-lain yang relevan dengan kegiatan belajar. Oleh karena itu lakukanlah sesuatu dengan efisien dan akan diperoleh hasil yang memuaskan dan kelak akan berguna untuk ke depannya.

\section{B. Petunjuk cara belajar yang efisien.}

Sukses hanya akan tercapai jika disertai dengan usaha keras. Tanpa usaha tak akan tercapai sesuatu apapun. Demikian juga di dalam belajar, hasil yang memuaskan tidak akan tercapai apabila tidak disertai dengan cara-cara belajar yang baik.

Menurut Nasution (1986:40-45) tentang cara-cara belajar yang baik meliputi:

1. Keadaan jasmani

2. Keadaan emosional dan social

3. Keadaan lingkungan 
4. Memulai pelajaran

5. Membagi pekerjaan

6. Adakan kontrol

7. Pupuk sikap yang optimis

8. Waktu bekerja

9. Buatlah suatu rencana kerja

10. Menggunakan waktu

11. Belajar keras tidak merusak

12. Cara mempelajari buku

13. Mempertinggi kecepatan membaca

14. Jangan membaca belaka

15. Cegah cramming

16. Membuat catatan

Selanjutnya menurut Slameto (2010:76-81) tentang cara belajar yang baik meliputi:

1. Keadaan jasmani

2. Keadaan emosional dan social

3. Keadaan lingkungan

4. Memulai belajar

5. Membagi pekerjaan

6. Adakan control

7. Pupuk sikap optimism

8. Waktu bekerja

9. Buatlah suatu rencana kerja

10. Menggunakan waktu

11. Belajar keras tidak merusak

12. Cara mempelajari buku

13. Mempertinggi kecepatan membaca

14. Jangan membaca belaka

Sedangkan menurut The Liang Gie (1982:8) Petunjukpetunjuk untuk belajar sungguh-sungguh dengan kemungkinan hasil yang baik meliputi:

1. Cara mengatur waktu belajar

2. Cara mengikuti pelajaran 
3. Cara membaca buku

4. Cara membuat ringkasan

5. Cara menghafal pelajaran

6. Cara menulis

7. Cara menempuh ujian

Dari kutipan di atas dapat diambil kesimpulan bahwa cara belajar yang efisien adalah sebagai berikut :

1. Cara membaca buku

Untuk menjadi seorang pembaca yang baik, setiap siswa perlu mengembangkan dan memiliki kebiasaan membaca yang baik. Disiplin pribadi yang baik sangat diperlukan untuk mengembangkan kebiasaan membaca agar dapat terlaksana secara otomatis dalam diri siswa tanpa banyak mengalami kesulitan. Agar siswa dapat membaca dengan efisien perlulah memiliki kebiasaan yang baik.

2. Cara mengatur waktu belajar.

Banyak siswa yang mengeluh kekurangan waktu belajar tetapi sesungguhnya mereka kurang dapat memanfaatkan waktunya dengan sebaik baiknya karena kebanyakan siswa sering kali tidak menyelidiki waktu yang terbaik baginya atau tidak mempunyai rencana belajar yang tepat. Jadwal belajar yang teratur akan membantu siswa mengontrol, memulai dan memeriksa sampai dimana tujuan belajar siswa tersebut tercapai. Dengan demikian dapat dilihat kekurangan atau kelemahan diri sendiri. Agar belajar dapat berjalan dengan baik dan berhasil perlulah seorang siswa mempunyai jadwal yang baik dan melaksanakannya dengan teratur dan disiplin.

3. Cara menghafal pelajaran

Agar dapat menghafal bahan dengan baik hendaklah memperhatikan syarat-syarat yang diberikan yaitu menyadari sepenuhnya tujuan belajar, mengetahui betulbetul tentang makna bahan yang dihafal, mencurahkan perhatian sepenuhnya sewaktu menghafal, menghafal 
secara teratur sewaktu kondisi badan dalam keadaan sehat. Menghafal dengan cara diam tapi otaknya mengingat-ingat, dapat dengan membaca keras/mendengarkan dan dapat juga dengan cara menulisnya

4. Cara menempuh ujian

Landasan utama dan kegiatan pokok untuk maju ujian adalah belajar dengan sebaik-baiknya. Siswa harus menyiapkan diri dengan belajar secara teratur, penuh disiplin dan konsentrasi yang cukup jauh sebelum ujian dimulai. Apabila siswa sudah belajar sebelum ujian maka waktu terakhir menjelang ujian dipergunakan untuk memperdalam pengetahuannya dan menghafal pelajarannya.

\section{Teori teori belajar}

Dalam sejarah perkembangan psikologi dikenal beberapa ahli psikologi. Tiap aliran psikologi tersebut memiliki pandangan tersendiri tentang belajar. Pandangan tersebut umumya berbeda satu sama lain dengan alasan tersendiri misalnya mendasarkan pada ilmu jiwa daya, tanggapan, asosiasi, trial and error dan sebagainya.

Menurut Slameto (2010:9-26) menyatakan bahwa teori belajar yakni:

1. Teori Gestalt

2. Teori belajar menurut J.Bruner

3. Teori belajar dari Piaget

4. Teori belajar dari R.Gagne

5. Purposeful learning

6. Belajar dengan jalan mengamati dan meniru (observation learning and imitation)

7. Belajar yang bermakna (meaningful learning)

Selanjutnya,Muhibbih Syah (2009:92-108) mengemukakan teori-teori belajar yakni :

1. Connectionism (koneksionisme)

2. Classical conditioning (Pembiasan Klasik)

3. Operant Conditioning (Pembiasan perilaku Respons) 
4. Contiguous Conditioning (Pembiasan Asosiasi Dekat)

5. Cognitive Theory (Teori kognitif)

6. Social Learning (Teori belajar Sosial)

Lebih lanjut, Oemar Hamalik (2004:35-40) mengemukakan teori teori belajar yakni :

1. Teori psikologi klasik

2. Teori psikologi daya

3. Teori mental state

4. Teori psikologi behaviourisme

5. Teori psikologi gestalt.

6. Teori connectionism

7. Teori psikologi Field Theory

Dari ketiga pendapat ahli di atas dapat disimpulkan bahwa teori belajar meliputi:

1. Teori Gestalt

Menurut teori ini jiwa manusia adalah suatu keseluruhan yang berstruktur. Suatu keseluruhan bukan terdiri dari bagian-bagian atau unsur-unsur. Unsur-unsur itu berada dalam keseluruhan menurut struktur yang telah tertentu dan saling berinteraksi satu sama lain. Contoh perhiasan emas bermakna dalam situasi pesta atau di took emas tetapi tidak bermakna di situasi padang pasir untuk mengatasi rasa haus dan dahaga,

2. Teori klasik

Menurut teori ini jiwa manusia terdiri dari jiwa(mind) dan badan (body) atau zat (matter).Jiwa dan zat ini berbeda satu sama lain. Badam adalah suatu objek yang sampai ke alat indra, sedangkan jiwa adalah suatu realita yang non material, mengontrol kegiatan badan serta bertanggung jawab. Zat sifatnya terbatas dan bukan suatu keseluruhan realita melainkan berkenaan dengan proses-proses material yang terkait pada hukum-hukum mekanis. Sedangkan jiwa merupakan fakta-fakta tersendiri dalam realita yg berbeda 
tetapi mempunyai sumber tersendiri yang mempunyai hak untuk berbicara dan bebas dari hukum mekanis.

3. Teori daya

Menurut teori ini jiwa manusia terdiri dari berbagai daya mengingat ,berfikir, merasakan, kemauan dan sebagainya. Tiap daya mempunyai fungsi sendiri-sendiri. Tiap orang memiliki semua daya-daya itu hanya berbeda kekuatannya saja. Agar daya-daya itu berkembang maka daya-daya itu perlu dilatih sehingga dapat berfungsi.

4. Teori connectionism

Teori ini mempunyai doktrin pokok yakni hubungan antara stimulus dan respons, asosiasi dibuat antara kesan pengadaan dan dorongan untuk berbuat. Ikatan atau koneksi dapat diperkuat atau diperlemah serasi dengan banyaknya penggunaan dan pengaruh dari penggunaan itu

\section{Prinsip-prinsip belajar}

Belajar itu merupakan usaha yang dilakukan seseorang untuk memperoleh perubahan. Perubahan yang terjadi dalam diri seseorang banyak sekali baik sifat maupun jenisnya karena itu sudah tentu tidak setiap perubahan dalam diri seseorang merupakan perubahan dalam arti belajar. Perubahan yang diperoleh dengan belajar harus didasarkan dengan beberapa prinsip agar dapat berhasil.

Menurut Slameto (2010:27-28) mengemukakan prinsipprinsip belajar:

1. Berdasarkan prasyarat yang diperlukan untuk belajar

2. Sesuai hakikat belajar

3. Sesuai materi atau bahan yang dipelajari

4. Syarat keberhasilan belajar

Selanjutnya Oemar Hamalik (2004:31) mengemukakan prinsip-prinsip belajar:

1. Proses belajar ialah pengalaman, berbuat, mereaksi dan melampaui (under-going) 
2. Proses itu melalui bermacam macam ragam pengalaman dan mata pelajaran yang terpusat pada suatu tujuan tertentu.

3. Pengalaman belajar bersumber dari kebutuhan dan tujuan murid sendiri yang mendorong motivasi yang kontinyu.

4. Pengalaman belajar dan hasil belajar disyarati oleh hereditas dan lingkungan.

5. Proses belajar dan hasil usaha belajar secara materiil dipengaruhi oleh perbedaan-perbedaan individual dikalangan murid.

6. Proses belajar berlangsung secara efektif apabila pengalaman-pengalaman dan hasil-hasil yang diinginkan disesuaikan dengan kematangan murid.

7. Proses belajar yang baik apabila mengetahui status dan kemajuan.

8. Proses belajar merupakan kesatuan fungsional bertalian satu sama lain tetapi dapat didiskusikan secara terpisah.

9. Proses belajar berlangsung secara efektif di bawah bimbingan yang meransang dan membimbing tanpa tekanan dan paksaan.

10. Hasil-hasil belajar adalah pola-pola perbuatan, nilai-nilai, pengertian-pengertian, sikap-sikap dan keterampilan.

11. Hasil-hasil belajar diterima oleh murid apabila memberi kepuasan pada kebutuhannya dan berguna serta bermakna baginya.

12. Hasil-hasil belajar dilengkapi dengan jalan serangkaian pengalaman-pengalaman yang dapat dipersamakan dan dengan pertimbangan yang baik.

13. Hasil-hasil belajar itu lambat laun dipersatukan menjadi kepribadian dengan kecepatan yang berbeda beda.

Lebih lanjut The Liang Gie (1982:37) mengemukakan prinsip-prinsip belajar:

1. Agar seseorang benar-benar belajar ia harus mempunyai suatu tujuan. 
2. Tujuan itu harus timbul dari atau berhubungan dengan kebutuhan hidupnya dan bukan karena dipaksa oleh orang lain.

3. Orang itu harus bersedia mengalami bermacam macam kesukaran dan bertekun berusaha untuk mencapai tujuan yang berharga baginya.

4. Belajar itu harus berbukti dari perubahan dalam kelakuannya.

5. Di samping tujuan pokok yang hendak dicapai, diperolehnya bila hasil-hasil dalam bidang lain.

6. Belajar lebih berhasil dengan jalan berbuat atau melakukan.

7. Seorang belajar sebagai keseluruhan, tidak dengan otaknya saja tetapi juga jasmaniah dan emosinya.

8. Dalam hal belajar seseorang memerlukan bantuan dan bimbingan dari orang lain.

9. Untuk belajar diperlukan "Insight".

10. Di samping mengajar tujuan belajar yang sebenarnya, seorang sering mengajar tujuan-tujuan lain.

Dari uraian di atas dapat disimpulkan bahwa prinsipprinsip belajar meliputi:

1. Proses belajar ialah pengalaman, berbuat, mereaksi dan melampaui (under-going).

2. Agar seseorang benar-benar belajar ia harus mempunyai suatu tujuan.

3. Belajar lebih berhasil dengan jalan berbuat atau melakukan.

4. Tujuan itu harus timbul dari atau berhubungan dengan kebutuhan hidupnya dan bukan karena dipaksa oleh orang lain.

5. Proses belajar yang baik apabila mengetahui status dan kemajuan. 
Tujuan akhir seseorang belajar adalah untuk memperoleh pengetahuan agar dapat dimanfaatkan sebagai bekal kemanapun melangkah. Belajar dapat dilakukan di sekolah ataupun diluar sekolah dimana belajar itu dapat berlangsung dengan sengaja ataupun tidak sengaja. Dengan mempelajari uraian prinsip tersebut maka siswa akan dapat menyusun sendiri prinsip belajar yang dapat dilaksanakannya dan dapat mendorong pencapaian tujuannya. 